\title{
Commercial Insurance as a Tool of Consumer Protection in the Czech Republic
}

\author{
Eva Ducháčková*
}

\begin{abstract}
:
Guarantee insurance is used by the state to solve some questions of consumer protection. To be specific it is insurance of tour operators against bankruptcy and insurance of employment agencies against bankruptcy. In both cases the insurance covers business risks of businesses and legal entities and that is the reason why the use of guarantee insurance in this context brings about several problems. On the one hand there are theoretical problems which deal with interpretation and explanation of the nature and principles of insurance and their application to insurance products and also problems concerning risk assessment of these products. On the other hand there are problems which deal with practical application and which are connected with the fact that there is no big interest in this kind of guarantee insurance among insurers with regard to their nature. Issues which approach the problem of consumer protection by means of commercial insurance are also related to the perception and understanding of insurance. Consumers demand full insurance coverage, however, taking into account the regulation of insurance market and the nature of insurance it is not possible to guarantee full insurance cover of losses which are caused by bankruptcy of a tour operator or an employment agency.
\end{abstract}

Key words: Tour operator; Employment agency; Guarantee insurance; Obligatory insurance.

JEL classification: G22, G29, G30.

\section{Introduction}

Consumer protection is an issue which is currently being addressed in different areas of economic life. In some cases commercial insurance has been used by the state as an alternative tool of consumer protection. Especially in areas where problems with financial losses of consumers are involved and where it has already happened that consumers suffered financial losses as a result of business activities.

Tour operators and employment agencies belong in the Czech Republic to businesses whose activities may result in financial losses of consumers and thus they are affected by attempts to compensate consumers for their losses by the use of commercial insurance. There is an obligation for tour operators and employment agencies to take out commercial insurance against bankruptcy if they

* Eva Ducháčková; University of Economics in Prague, Department of Banking and Insurance, Winston Churchilla Square 4, 13067 Prague 3, Czech Republic, <duchack@vse.cz>.

The article is processed as an output of a research project Trends in the banking and insurance sectors in a changing financial markets registered by the University of Economics under the registration number IGA F1/21/2016. 
want to conduct business and hold the licence in the Czech Republic. The insurance, which is used, has a character of guarantee insurance.

The name itself - insurance against bankruptcy - stirs polemic as conducting business and the likelihood of bankruptcy are associated and linked to deliberate risk. In the theoretical point of view, deliberate risks are not supposed to be a subject matter of commercial insurance. Commercial insurance entails, in the theoretical point of view, net risks, i.e. risks which if taken may have only a negative impact (in contrast to deliberate risks which if taken may result in both a positive and a negative outcome) and concurrently net risks are not caused deliberately (in the course of conducting business companies deliberately take risks while expecting a positive outcome of such risks).

The aim of this article is to analyse and assess the role commercial insurance plays in consumer protection in context of the business of tour operators and employment agencies. It also evaluates the problems regarding the use of relevant insurance products, notably in the theoretical point of view.

\section{Data and Methodology}

In this paper the author examines the role of obligatory insurance, insurance of tour operators and insurance of employment agencies against bankruptcy in addressing issues related to the functioning of the business entities. In processing the contribution were used the methods of description, deduction, analytic comparisons and literature review. The author uses information available primarily from theoretical books related to insurance issues and resource materials of legislation and statistics information.

\subsection{Obligatory insurance of tour operators}

The insurance of tour operators was introduced in the Czech Republic as mandatory contractual insurance in the year 2000 (October 1st). The reason for the legal regulation of the activity of tour operators and the introduction, at the same time, of the mandatory insurance of tour operators in the Czech Republic against bankruptcy was the attempt to solve the problems connected with the functioning of tour operators in the second half of the 1990s. During that period, tour operators were going bankrupt, with a negative impact on their clients (in 1997 alone, six thousand clients of tour operators got stranded abroad without any provision of repatriation). These problems were caused by the rapid development of the tourist industry in the 1990s, which was connected with the growth in the number of tour operators (in 1989, there were only six tour operators in Czechoslovakia, while in 1990, the number had already reached 600). Insurance is one of the tools that can be used to relieve the negative impact of the bankruptcy of tour operators on their clients (no provision of repatriation and no financial 
compensation for services paid for but provided only in part or not all). In addition to insurance, tools such as a guarantee fund, a pledged deposit or bank guarantee may also be used.

The insurance of tour operators against bankruptcy was introduced in the conditions of the Czech Republic in the form of mandatory contractual insurance. That means that taking out insurance is a precondition for the commercial activity of a tour operator, a tour operator being defined as "commercial entity, which, on the basis of a concession, is authorised to organise, offer and sell excursions" (Law no.159/1999 Coll., on certain conditions of commercial activity and the performance of certain activities in the field of tourism). The term "excursion" is taken to mean the combination of at least two of the following services: transport, accommodation, other tourist services constituting a significant part of the excursion, or whose cost constitutes at least $20 \%$ of the cost of the excursion (Law no.159/1999 Coll., on certain conditions of commercial activity and the performance of certain activities in the field of tourism).

This means that mandatory insurance does not apply to the services of so-called travel agencies, neither does it apply to those services offered by tour operators which do not fall within the definition of an excursion (individual tourist services, the sale of objects connected with tourism etc.)

The insurance of tour operators is, by its nature, guarantee insurance, that is, insurance which is meant to cover the obligations which the insurance policy holder has towards other parties (Ducháčková, 2015, p. 206). According to the law governing this type of insurance, the function of the insurance is to cover losses incurred by the clients of a tour operator in the event of its bankruptcy, namely:

- the total lack of provision of a purchased service,

- the failure to provide contractual services in the location of the excursion (for example, failure to provide a transfer from an airport, or a lack of accommodation),

- failure to provide repatriation to the client's home country,

- interruption of the client's stay.

From the point of view of insurance theory, the question of the nature of the risks covered when applying the mandatory insurance of tour operators is a problematic one. According to insurance theory, insurance as a financial category is focused on covering so-called net risks (Rejda, 2005) the negative impact of which is determined by completely random factors. The opposite of net risks are so-called calculated risks, which can be influenced by an interested party. From a theoretical point of view, the character of this type of insurance is, therefore, questionable, as the major causes of the bankruptcy of tour operators include the wrong business plan, the underestimation of risks, a decline in demand, a too narrow focus on a particular type of tourism or region, and the devaluation of the Czech crown (In 
the past, the cause of the bankruptcy of tour operator sometimes turned out to be fraudulent practices, or even the establishment of a tour operator with the intention to commit fraud). The fact that the insurance of tour operators is in conflict with the very nature of insurance as a financial category gives rise to some problems connected with the operation of that type of insurance.

\subsection{An insurance pool}

The provision of insurance to cover the bankruptcy of tour operators has meant, since October 2000, on the one hand, a new business opportunity for insurance companies, while, on the other hand it has been a relatively questionable product. The insurance companies were given the task of introducing a new type of product (at that time, even guarantee insurance was not widespread on the Czech market). They had no experience of covering that type of risk. Before offering insurance products, it is necessary first to determine the presumed size of the possible indemnity payments in order to set the level of the insurance premium. In the case of the insurance of tour operators, it is necessary to evaluate the seriousness of the risk (financial risk). When an insurance product is introduced it is very complicated to evaluate in advance the probability of bankruptcy and the extent of the damage it may cause.

Concerns about the size of the risk (especially following the development in the second half of the 1990s) led the insurance companies to unite in a co-insurance pool (Ducháčková, 2015, p. 107), in order to cover the possible impact of the risks. A co-insurance pool is a voluntary association of insurers established to create a greater insurance portfolio and joint cover of large-scale insurance events. At the same time, a co-insurance pool means that the associated insurers offer an insurance product under the same conditions, and that one insurer is empowered to do business in the name of all the members of the pool. It also means that the coinsurance pool can hedge its assets as whole. This characteristic clearly means that, on the one hand, risks are covered jointly, while on the other hand the pool has an impact on the principles of market competition. That is why the pool was granted a two-year exception for its activity by the Office for the Protection of Competition valid from 12.1.2001 (Ruling of the Office for the Protection of Competition on the granting of an exception). 


\section{Tab. 1: Structure of the co-insurance pool}

\begin{tabular}{lr}
\hline Insurer & Share in \% \\
\hline Allianz pojišt'ovna & 11,11 \\
Česká podnikatelská pojišt'ovna & 11,11 \\
Česká pojišt'ovna & 11,11 \\
Česko - rakouská pojišt'ovna & 5,56 \\
ČS - Živnostenská pojišt'ovna & 11,11 \\
Generali Pojištovna & 16,67 \\
IPB Pojištovna & 11,11 \\
Komerční pojišt'ovna & 11,11 \\
Kooperativa pojištovna & 11,11 \\
\hline Total without reinsurance & 100,00 \\
\hline
\end{tabular}

Source: Ducháčková, Radová, Daňhel, 2015.

Membership of the pool (see Tab. 1) brings several advantages, above all:

- the distribution and minimisation of risk through the acquisition of quality reinsurance abroad and also the reduction of administrative costs,

- a certain amount of standardisation of the evaluation of risks of those parties interested in insurance, which contributes to the harmonisation of the insurance conditions of tour operators of comparable type,

- a simpler system for the clients thanks to the centralisation of the reporting of loss occurrence and the harmonisation of conditions for the payment of damages.

The division of capacity within the pool means that when there is an insurance claim incurring indemnity of less than 45 million Czech crowns, the amount is paid out by the members of the pool according to a given ratio. If the indemnity exceeds that amount, the difference between the amount to be paid and 45 million Czech crowns is covered by the reinsurer up to the total capacity of the pool (to a maximum of 150 million Czech crowns). If the amount required to cover exceptionally high risks exceeds that total capital, the leading insurer provides individual reinsurance to the required amount.

During the autumn of 2002, the Office for the Protection of Competition issued a ruling (Ruling of the Office for the Protection of Competition on the granting of an exception) which extended the validity of the exception from the ban on an agreement on a joint approach by insurers towards guarantee insurance in the case of the bankruptcy of a tour operator until 31.12.2003. Nevertheless, the granting of that exception was subsequently restricted by several conditions, which were, however, not fulfilled by the insurance companies (for example, the setting of a 
unified tariff scale, the lack of individual reinsurance, and, above all, the lack of competitive insurance). For that reason, the insurance pool terminated its activity at the end of 2003, which, in fact, led to the demonopolisation of the market for that type of insurance.

At the beginning of 2004, there were only five insurers on the market who offered insurance against the bankruptcy of a tour operator. During the course of the following years, the structure of that market has changed. Currently, the insurance of tour operators is offered by a relatively small number of insurance companies: Česká podnikatelská pojištovna, ERV pojištovna, Generali pojištovna, Slavia pojišt'ovna, UNIQA pojišt'ovna, and the Slovak insurance company Union. This lack of interest in providing insurance for tour operators is due to the nature of the insurance, its level of risk and problems connected with providing insurance as a matter of principle.

\subsection{Problems connected with the insurance of tour operators}

There is a relatively large number of tour operators on the Czech market (see Fig. 1). The tour operators are insured by six insurance companies (see Tab. 2).

Fig. 1: Number of tour operators on the Czech market

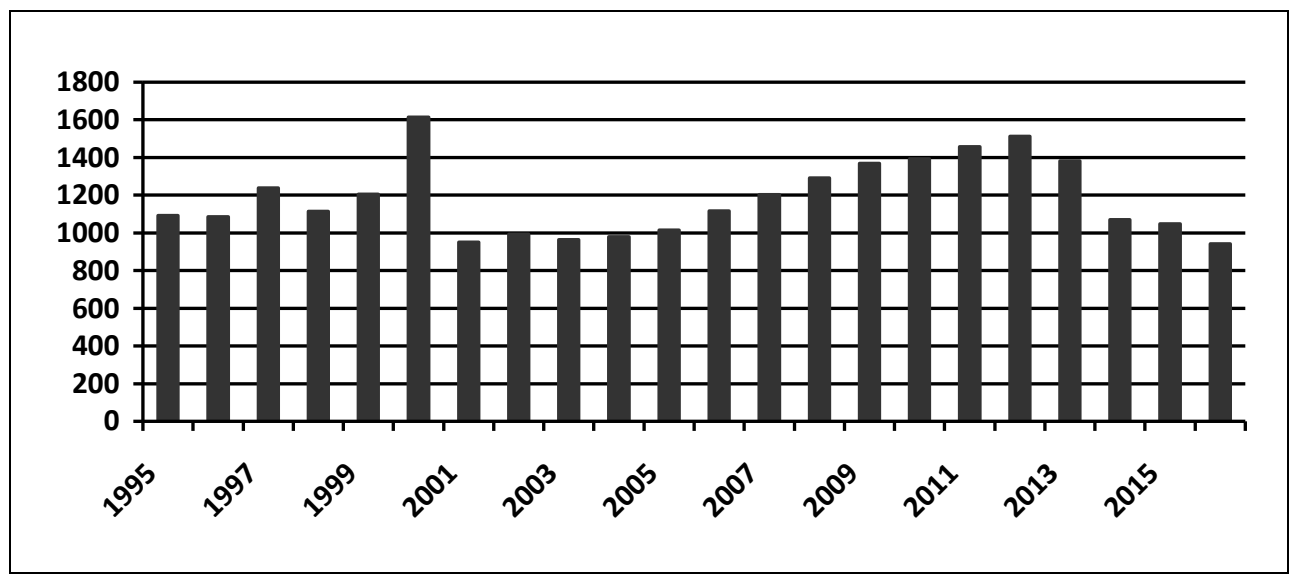

Source: Insured tour operators, Ministry for Local Development.

Tour operators are obliged to take out insurance, although there have, of course, been cases where that obligation has not been fulfilled. If the insurance of a tour operator expires and the operator continues to sell excursions, the lack of insurance usually only becomes apparent when a problem arises. In the case of a formerly insured, but now uninsured tour operator, according to the principles of insurance, the insurance company which insured the tour operator does not pay out indemnity to the tour operator's clients. Practically speaking, from the point of view of the timescale of the insurance of tour operators, the principle of loss 
occurrence is applied, which means that insurance applies to excursions sold during the period when the tour operator's insurance policy was valid, even if the loss occurs when the policy is no longer valid.

In addition, there is a problem with the definition of the term "excursion", which is the subject of the insurance. If a tour operator intentionally divides the services it offers into parts (for example, accommodation, transport), the services of the operator are no longer insured and, in the case of bankruptcy, the clients have no claim to indemnity.

\section{Tab. 2: Distribution of tour operators insured by individual insurance companies (2014)}

\begin{tabular}{lr}
\hline Insurance companies & $\begin{array}{l}\text { Number of insured } \\
\text { tour operators }\end{array}$ \\
\hline Česká podnikatelská pojišt'ovna & 340 \\
ERV pojišt'ovna & 126 \\
Generali pojišt'ovna & 296 \\
Slavia pojišt'ovna & 19 \\
Union pojišt'ovna & 161 \\
UNIQA pojišt'ovna & 107 \\
\hline Total & $\mathbf{1 0 4 9}$ \\
\hline
\end{tabular}

Source: Insured tour operators, Ministry for Local Development.

Another problematic issue is the size of the insured sum. According to the law, a tour operator must take out insurance to cover a sum equal to at least $30 \%$ of its annual planned takings from the sale of excursions. At the same time, the size of the insured sum has an impact on the insurance premium (alongside other factors such as the destination countries of the excursions, the means of transport, the evaluation of the creditworthiness of the tour operator, the structure of its assets, its liquidity etc.). If the insured sum is underestimated and an insurance claim is made, the insurance company, according to the principles of insurance, pays out indemnity only up to the agreed insured sum. In some cases this situation has arisen following the bankruptcy of tour operators. The clients did not receive indemnity in full. In some cases this has led to litigation, and some insurance companies have been required to pay indemnity greater than the agreed insured sum. This approach displays a lack of understanding of the principles of insurance, as insurance companies, when taking on risks by ensuring them, and when evaluating the risks (in order to set the insurance premium), base their decisions on the insured sum. An insurance company cannot assume the pay-out of indemnity greater than the agreed insured sum. If that were required of an insurance company, it would mean the possibility of moral hazard on the part of the tour operators and the rejection of the basic principles of insurance theory. It would also be in conflict with the rules on the economic activity of insurance companies, 
especially those rules found in the law on the insurance business (any proposed law on the tourist industry requiring insurance companies to pay indemnity greater than the agreed insured sum could deter commercial insurance companies from offering that type of insurance). One proposed solution to these problems is to set a minimum insured sum, which, of course, is also problematic because of the diverse sizes of tour operators (measured by takings).

\section{Tab. 3: Number of bankruptcies of tour operators}

\begin{tabular}{lccccccccccccccc}
\hline Year & $\mathbf{0 1}$ & $\mathbf{0 2}$ & $\mathbf{0 3}$ & $\mathbf{0 4}$ & $\mathbf{0 5}$ & $\mathbf{0 6}$ & $\mathbf{0 7}$ & $\mathbf{0 8}$ & $\mathbf{0 9}$ & $\mathbf{1 0}$ & $\mathbf{1 1}$ & $\mathbf{1 2}$ & $\mathbf{1 3}$ & 14 & 15 \\
\hline $\begin{array}{l}\text { Number of } \\
\text { cases }\end{array}$ & 3 & 4 & 5 & 4 & 4 & 1 & 3 & 1 & 3 & 9 & 10 & 8 & 5 & 3 & 6 \\
\hline
\end{tabular}

Source: Number of bankruptcies of tour operators, Ministry for Local Development.

Insurance is a tool used to solve the problem of randomness, which is why the requirement to pay out indemnity even in cases where the bankruptcy of a tour operator has demonstrably been caused intentionally, which may generally be called insurance fraud, is wrong (in other branches of insurance, indemnity is not paid in cases where there is proof of insurance fraud).

In the light of the number of bankruptcies of tour operators in different years (see table 3), and the fact that in many cases the agreed insured sum was insufficient, it is necessary to deal with these issues effectively.

\subsection{Insurance of employment agencies against bankruptcy}

Insurance of employment agencies against bankruptcy responses to potential problems that employment agencies may face while they conduct business and their impact on clients - employees of employment agencies. In the Czech Republic there has been a legal obligation for employment agencies to take out insurance since 2011 (April 2011) based on amended Act on Employment (Act on Employment, No 435/2004 Coll.). Without having this type of insurance employment agencies are not allowed to conduct business.

This insurance covers situations when an employment agency is not able to pay out remuneration to employees for the work they did. The subject matter of the insurance is the obligation of employment agencies to their employees - to pay them out the remuneration stipulated in the contract if employment agencies are not able to pay out these earnings due to bankruptcy (Ducháčková, 2015, p. 207). The insurance company assumes the contractual obligations stipulated in employment contracts (i.e. the obligation to pay out the remuneration) of employees of the employment agency in case of its bankruptcy (insolvency). Fig. 1 shows the relation between employment agencies, employees and users (legal entities using the service of an employment agency). 
Fig. 2: Relation: employee - employment agency - user

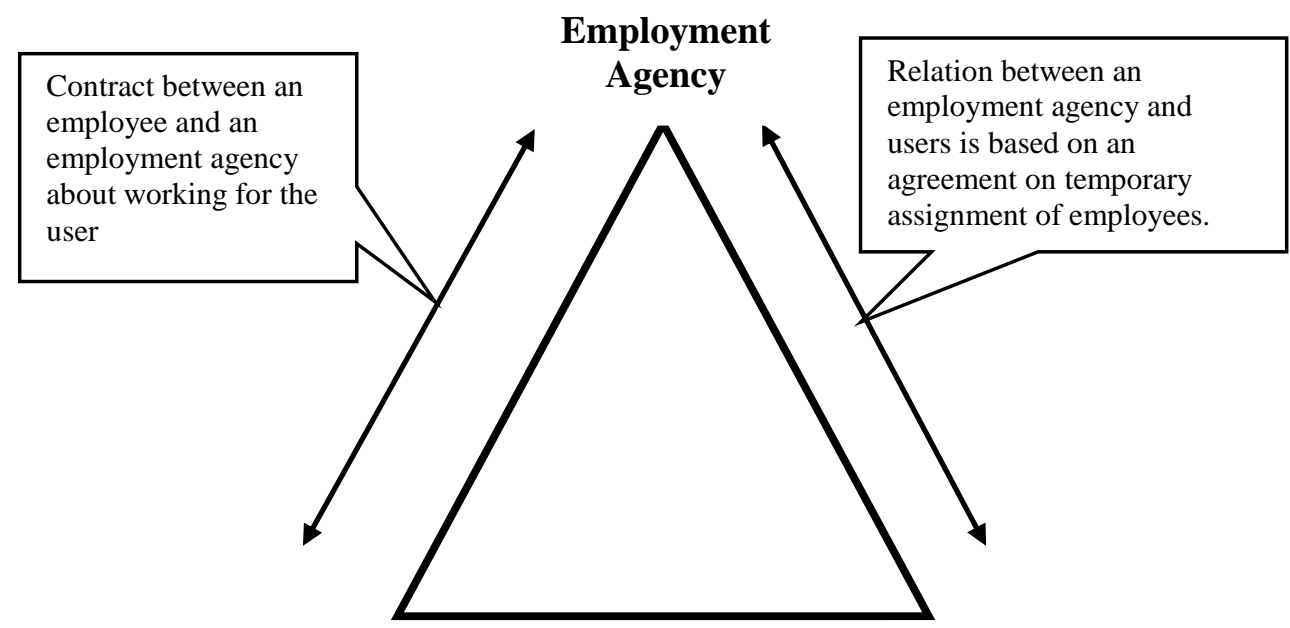

Employees

Users - Employers

Source: based on PICHRT, J. and al.: Agency employment in complex contexts, p.75.

Insurance of employment agencies against bankruptcy can be provided only by insurance companies which are qualified (under the Insurance Act) to offer guarantee insurance. In fact, the nature and content of insurance of employment agency mean that insurance companies have no big interest in providing this type of guarantee insurance. According to the data, this type of insurance is provided only by four insurance companies ${ }^{1}$, however, in reality only two insurance companies provide this insurance - Slavia a Česká pojišt’ovna. Slavia insurance company was the first company which started to offer this type of insurance (Slavia belongs to smaller insurance companies operating in the Czech insurance market). The introduction of insurance of employment agencies against bankruptcy meant a stronger media presence and visibility for Slavia insurance company as this kind of insurance product had not been offered by any other insurance company at that time. Although the offered insurance did not fulfilled the scope of compulsory insurance of employment agencies (as stipulated in the act) - it covered only the bankruptcy of the employment agency, not the bankruptcy of the employment agency and all its users as required originally - the Ministry of Labour and Social Affairs approved the extent of insurance coverage and considered it adequate to meet the legally binding obligation. Currently, Slavia insurance company dominates the market of this kind of obligatory

Insurance companies Slavia, Pojišt'ovna Uniqua, Atradius, Česká podnikatelská pojišstovna, Česká pojišt'ovna. 
insurance. The biggest employment agencies operating in the Czech Republic e.g. Manpower, Grafton Recruitment entered into insurance contracts with Slavia insurance company. ${ }^{2}$

According to the act, the insured sum must cover the minimum amount of three monthly earnings of employees who are assigned by the employment agency to the users (i.e. only seconded employees are involved, not direct employees of the employment agency). Concurrently, the insurance compensation of three monthly earnings is paid out to affected employees in case of bankruptcy of the employment agency. Insurance of employment agencies increases operating costs for employment agencies. Hence they have a negative attitude towards insurance against bankruptcy. The increase in costs also puts employment agencies at a disadvantage against other subjects in the market engaged in the same business of employment.

\section{Results and Discussion}

The main issue of insurance of employment agencies and insurance of tour operators is the risk assessment of businesses. They actually represent insurance of financial losses and are closely related to the approach to doing business. Moreover, the use of obligatory insurance may be linked to moral hazard in business.

A fierce discussion about insurance of tour operators was stirred by the fact that insurance companies use the limit of cover by the construction of their insurance products. Affected clients particularly could not understand why they did not receive in case of bankruptcy of the tour operator the insurance cover equal to the amount of real financial losses caused by the failure of tour operators to meet their liabilities. They received the insurance cover in a proportional amount with regard to the fact that the contracted insured sum (by tour operators) was not sufficient. Misunderstanding of the core principles of commercial insurance resulted in a situation when state authorities and institutions demanded full (limitless) insurance cover offered by insurance companies. In this case it is extremely difficult for insurance companies to assess risks and calculate prices of insurance policies, though insurance regulatory authorities insist on that. Provided that, insurance companies would be forced to exclude insurance of tour operators against bankruptcy from their product portfolio. Proposals to replace obligatory guarantee insurance with bank guarantee did not receive a positive response either since

2 Employment agencies have only a small share of employment market: employees of employment agencies account for $0,7 \%$ of the total amount of employees, although their share in the EU countries is about $1,7 \%$. There are about 1600 employment agencies operating in the market. (http://www.novinky.cz/kariera/363452-ministerstvo-prace-chce-pritvrdit-pravidla-pro-agenturnizamestnavani.htm). 
there is a similar problem with full (limitless) cover by bank guarantee as it is with guarantee insurance.

Current legal adjustment to obligatory insurance meets the need for a limit of cover required by insurance companies, however, higher liability by setting the insurance sum (limit of cover) is demanded. In future, multi-source financing of financial losses covers for clients of tour operators in case of their bankruptcy will have to be used which means a combination of obligatory insurance and further tools for instance establishment of a guarantee fund to cover losses whose extent would be larger than the insured sum taken out by tour operators.

The same approach, i.e. the cover of losses above the limit of cover, could be also applied to the cover of losses for employees of employment agencies in case of their bankruptcy. The main issue here, however, is not the limit of cover (considering the construction of this insurance), but the extent of subjects involved in obligatory insurance.

The original intention and aim of obligatory insurance - to cover the losses in case of bankruptcy of employment agencies and all their users - was not accepted by insurance companies. This extent of cover would bring about very difficult risk assessment for insurance companies because insurance companies would be forced to assess risks of several businesses and legal entities (all users and the employment agency) whose structure may change during the insurance policy validity period. It means that no protection of seconded employees is guaranteed in case of bankruptcy of a user (employer). The same holds for direct employees of employment agencies and thus the questions arises whether the original approach to the protection of employees of employment agencies is not too excessive.

In some cases an enormous extent of losses caused by tour operators and employment agencies cannot be excluded. Thus risk diversification is required by insurance companies - the use of reinsurance or other risk diversification tools (e.g. insurance pool). Therefore, the question of reinsurance plays a key role in decision-making of insurance companies whether or not they will offer this type of insurance.

There are other ways of resolving the impact of the bankruptcy of a tour operators and employment agencies, principally a guarantee fund, a pledged deposit, bail bond insurance, or a bank guarantee.

A guarantee fund is a solidarity fund, to which all tour operators or employment agencies would contribute (each would deposit a certain amount on the setting-up of the fund, while in the following years they would contribute according to their takings.) This approach would require the establishment of an institution to administer the guarantee fund. (This model is used in several European countries, for example, Denmark, France and Sweden for tour operators). 
In the case of a pledged deposit, each tour operator or employment agency would open an account, in which a prescribed sum of financial resources would be deposited. The problem with this approach is the fact that, in the case of the bankruptcy, the pledged account would become part of the bankrupt company's estate, the immediate payment of indemnity would not be ensured and the clients would not obtain satisfaction.

Another form of deposit is so-called bail bond insurance. Money is deposited with a commercial insurance company, and, in the case of the bankruptcy of the tour operator, the deposit is used to repatriate the clients and, through insurance, to ensure a refund.

A bank guarantee is created by the declaration in writing by a bank in a letter of guarantee that it will compensate the creditors to the amount specified in the letter of guarantee, should the tour operator or employment agency not fulfil its contractual obligations. Before providing the bank guarantee, the bank would check the financial state of the tour operator, just as an insurance company would before insuring the tour operator, except that, of course, the bank, unlike the insurance company, would not ensure the return of the clients' money.

For the consequences of bankruptcy of travel agency or employment agency on clients is the best (of these options) using of the guarantee fund. We can also consider a combination of obligatory insurance and guarantee fund. The guarantee fund would paid damages above the limit within the obligatory insurance.

\section{Conclusion}

Guarantee insurance in the Czech insurance market has a relatively short history. The state has used guarantee insurance to solve some questions of consumer protection, In the Czech Republic this has been done by the means of two types of obligatory insurance. It is possible to say that - to a certain extent - the liability for business risks is transferred from selected businesses to commercial insurance companies. Regarding tour operators and employment agencies it is the insurance against bankruptcy. A theoretical problem of these insurance products lies in the nature of insurance and its principles. The economic theory of insurance defines as one of the key principles of insurance as financial category the fact that insurance covers only net risks. Nevertheless, the business of tour operators and employment agencies involves deliberate risk (based on the economic theory of insurance deliberate risks are not taken into account). The theoretical problem of the coverage of deliberate risks and the possibility of moral hazard are intertwined and thus incompatible with the nature and core principles of insurance.

A complex question of the described insurance products poses on one hand the setting of the insured sum (limit of cover), on the other hand the right risk assessment, i.e. calculation of price of insurance policies and stipulation of other 
insurance technical parameters as technical provisions and sufficient reinsurance. This creates a situation where there is only little interest by insurers in guarantee insurance, namely in insurance of tour operators and insurance of employment agencies against bankruptcy - the insurance is offered only by limited amount of insurers (insurance of tour operators by six insurers, insurance of employment agencies only by two insurers).

In general, there are further tools to solve the problems of consumer protection problems of clients of tour operators. It means particularly the establishment of guarantee fund, bank guarantees or blocked deposit. With regard to the nature of financial risks which the obligatory insurance of tour operators deals with, it would be effective to use multi-source coverage of clients' financial losses in case the tour operator goes bankrupt. It would be especially helpful to combine obligatory insurance with the establishment of a guarantee fund. Financial losses would be covered from this fund in case the tour operator did not have a sufficient limit of cover/insured sum since several problems were caused by an insufficient limit of cover in the past.

\section{References}

Act No. 159/1999 Coll. (Law No. 159/1999 Coll.), on certain conditions of commercial activity and the performance of certain activities in the field of tourism. Available from: <http://www.podnikatel.cz/zakony/zakon-c-159-1999-sbo-nekterych-pod-minkach-podnikani-v-oblasti-cestovniho-ruchu-a-o-zmenezakona-c/>. [20 February 2016].

Act on Employment, No 435/2004 Coll. Available from: <http://business. center.cz/business/pravo/zakony/zamestnanost/>. [2 February 2016].

Ducháčková, E., 2015. Pojištění a pojištovnictví. Praha, Ekopress.

Ducháčková, E., Radová, J., Daňhel, J., 2015. The role of the insurance of tour operators against bancruptcy in the conditions of the Czech republic, Czech Hospitality and Tourism Papers 25, 30-39.

Insured tour operators, Ministry for Local Development. Available form: $<$ http://www.mmr.cz/cs/Regionalni-politika-a-cestovni-ruch/Cestovni-

ruch/Dovolena-bez-starosti/Cestujete-s-cestovni-kancelari>. [10 February 2016].

Number of bankruptcies of tour operators, Ministry for Local Development, Available from: <http://www.compet.cz/hospodarska-soutez/sbirky-rozhodnuti/ 903/>. [13 February 2016].

Pichrt, J., et al., 2013. Agenturní zaměstnávání v komplexních souvislostech, Praha, C. H. Beck.

Rejda, G E., 2005. Principles of risk management and insurance. Boston, AddisonWesley. 
Ducháčková, E.: Commercial Insurance as a Tool of Consumer Protection in the Czech Republic.

Ruling of the Office for the Protection of Competition on the granting of an exception. Available from: <http://kraken.slv.cz/UOHSS001/2000>. [14 February 2016].

Ruling of the Office for the Protection of Competition on the granting of an exception. Available from: <http://www.compet.cz/hospodarska-soutez/sbirkyrozhodnuti/903>. [23 February 2016]. 